ISSN : $2338-4794$

Vol 3 No. 3 September - Desember 2016

\title{
ANALISIS PENGARUH VARIANS ANGGARAN PENJUALAN DAN ANGGARAN \\ BIAYA PENJUALAN TERHADAP LAPORAN LABA RUGI. STUDI PADA PT COMBIPHAR PERIODE 2012 - 2014
}

\author{
Watini $^{1)}$ \\ Hayuningtyas Pramesti Dewi ${ }^{2)}$
}

\begin{abstract}
This Paper aims to analyze impact of sales and sales cost budget variance to Income Statement in PT Combiphar in 2012 - 2014. This paper analyzed quantitevely by Regression analysis. Data collected from PT Combiphar are sales budget, sales cost budget and Income Statement. Result of this study show that Income Statement impacted significantly by variance sales and sales cost budget in partial test, and by simultaneously both of variance sales and sales cost budget impact significantly to Income Statement in 57.6\%.

Keywords: Variance, Sales and Sales Cost Budget, Income Statement.
\end{abstract}

\section{PENDAHULUAN}

Penganggaran atau budgeting merupakan proses yang menghasilkan suatu rencana yang disusun secara sistematis yang meliputi seluruh kegiatan perusahaan, yang dinyatakan dalam unit (kesatuan) moneter berlaku untuk jangka waktu tertentu yang akan datang atau disebut anggaran (budget). Anggaran ini diperlukan untuk semua jenis perusahaan, tanpa anggaran perusahaan akan mengalami kesulitan dalam menjalankan operasinya. Kaitannya dengan penganggaran, anggaran penjualan merupakan salah satu bagian terpenting dari pengestimasian suatu anggaran, karena anggaran penjualan merupakan dasar dari pembuatan anggaran lainnya dan pada umumnya anggaran penjualan disusun terlebih dahulu selanjutnya barulah disusun anggaran lainnya.Oleh karena itu dalam penyusunannya harus dilakukan dengan benar. Kesalahan dalam penyusunan anggaran akan mengakibatkan anggaran lain pun secara otomatis menjadi salah.

Setelah anggaran penjualan disusun anggaran yang tidak kalah pentingnya adalah anggaran biaya operasional.
Kegiatan operasional adalah kegiatan yang dilakukan oleh perusahaan untuk menunjang aktivitas operasi perusahaan yang memerlukan adanya perencanaan dan pengendalian yang baik terhadap biaya yang digunakan.Salah satu anggaran yang termasuk kedalam anggaran operasional adalah anggaran biaya penjualan.Kegiatan penjualan merupakan salah satu kegiatan yang dilaksanakan perusahaan yang seringkali mengalami perubahan sesuai tuntutan perubahan kondisi pasar.Dalam melakukan kegiatan penjualan manajemen menghadapi masalah biaya, dan biayabiaya yang dikeluarkan untuk memasarkan produk semakin besar proporsinya dari keseluruhan biaya.Oleh karena itu, biaya yang dikeluarkan perusahaan perlu dikendalikan agar biaya-biaya yang dikeluarkan itu bermanfaat bagi pencapaian tujuan perusahaan.

Anggaran biaya penjualan dapat membantu manajemen dalam mengendalikan biaya penjualan.Dengan adanya pengendalian biaya penjualan diupayakan biaya-biaya yang dikeluarkan untuk kegitan penjualan sesuai dengan rencana kegiatan yang ditetapkan 
perusahaan supaya anggaran penjualan yang menjadi sasaran dapat tercapai.

PT Combiphar adalah perusahaan yang bergerak dibidang farmasi, yang menerapkan sistem penganggaran. Berdasarkan laporan anggaran penjualan dan laporan anggaran biaya selama 3 tahun yaitu dari tahun 2012, 2013, dan 2014 sering terjadi selisih (varians) antara anggaran dengan realisasinya. Anggaran perusahaan ditetapkan oleh presiden direktur, kemudian disampaikan ke kepala masing-masing divisi, terutama divisi marketing untuk selanjutnya dibuat anggaran yang spesifik perbrand. Kenaikan anggaran didasarkan pada keuntungan yang diharapkan dan prediksi keadaan dimasa yang akan datang. Anggaran penjualan dari tahun ke tahun cenderung meningkat walaupun anggaran yang ditetapkan pada tahun-tahun sebelumnya belum tercapai.Dan untuk anggaran biaya ditingkatkan pula secara proporsional. Realisasi dari anggaran penjualan berupa penjualan aktual dan realisasi dari anggaran biaya operasional berupa biaya aktual. Selisih antara penjualan dan biaya akan menghasilkan laba/rugi.Dengan demikian penelitian ini bertujuan untuk mengetahui varians anggaran penjualan dan varian biaya pemasaran pada produk Obat Batuk Hitam $(\mathrm{OBH})$ dan akibatnya terhadap Laba Rugi pada tahun 2012 - 2014 di PT Combiphar. Penelitian sejalan pernah dilakukan olehWatania, (2013), tentang analisa varians biaya operasional dalam mengukur efektifitas pengendalian biaya operasional pada kantor wilayah VI PT Pegadaian (Persero Manado), hasil penelitiannya menyimpulkan terjadi penyimpangan biaya baik itu penyimpangan tidak menguntungkan (unfavorable) atau penyimpangan menguntungkan (favorable). Namun untuk pengendalian terhadap biaya operasional sudah efektif, karena adanya usaha perbaikan yang dilakukan perusahaan pada setiap biaya yang terjadi penyimpangan.

\section{TINJAUAN LITERATUR}

Menurut Ari Purwanti dan Darsono.P (2013:111) “Anggaran adalah rencana kerja yang dituangkan dalam angka-angka keuangan baik jangka pendek maupun jangka panjang".Sedangkan menurut Menurut Garrison Noreen Brewer (2013:382) “Anggaran (Budget) adalah rencana terperinci untuk masa depan yang diekspresikan dalam bentuk kuantitatif', dan menurut Menurut Rudianto (2013:64) "Anggaran adalah rencana kerja organisasi dimasa mendatang yang diwujudkan dalam bentuk kuantitatif, formal, dan sistematis".Dengan demikian, anggaran merupakan rencana kerja organisasi dimasa mendatang.Proses penyiapan anggaran disebut penganggaran.Menurut Ari Purwanti dan Darsono. P (2013:116), penganggaran bertujuan untuk: (1) memaksa manajer membuat rencana kerja, (2) tolak ukur mengevaluasi kinerja, (3) meningkatkan komunikasi dan koordinasi antar manajer, dan (4) membantu pengambilan keputusan.

Menurut Didit Herlianto (2015:8), untuk dapat melakukan penaksiran secara lebih akurat dalam penyusunan anggaran, diperlukan berbagai data, informasi dan pengalaman yang merupakan faktor-faktor yang harus dipertimbangkan dalam menyusun anggaran. Faktor-faktor yang mempengaruhi penyusunan anggaran dapat dibedakan menjadi dua kelompok, sebagai berikut: 1) Faktor-faktor Intern, yaitu data, informasi dan pengalaman yang terdapat dalam batas-batas tertentu masih bisa disesuaikan dengan keinginan atau 
kebutuhan untuk periode anggaran yang akan datang. 2) Faktor-faktor Ekstern, yaitu data, informasi dan pengalaman yang terdapat diluar perusahaan, tetapi mempunyai pengaruh terhadap kehidupan perusahaan.Menurut Rudianto (2013:67), walaupun anggaran yang harus disusun perusahaan terdiri dari berbagai jenis anggaran, tetapi pada dasarnya anggaran perusahaan dapat dikelompokan kedalam beberapa kelompok anggaran, yaitu: Anggaran induk, anggaran operasional, anggaran keuangan, anggaran berkelanjutan, dan anggaran yang selalu diperbarui.

$$
\text { Menurut Ari Purwanti dan }
$$

Darsono. P (2013:143), "Biaya standar adalah biaya yang ditetapkan terlebih dahulu sebelum proses produksi dimulai, atau sebelum suatu kegiatan dimulai".Standar dibuat berdasarkan kombinasi yang tepat antara pengalaman dan pengetahuan atau antara praktek dan teori.Pengalaman saja belum cukup untuk membuat standar yang baik, sebab pengalaman itu sifatnya sangat individual; pengetahuan (teori) saja juga tidak cukup untuk membuat standar yang baik karena teori sifatnya ideal.Standar mempunyai dua unsur fisik (volume kegiatan) dan keuangan (pendapatan dan biaya). Biaya standar yang lazim dalam suatu kegiatan bisnis adalah biaya dari: 1) Kegiatan Penjualan, 2) Kegiatan Produksi, 3) Kegiatan komersial.

Menurut Ari Purwanti dan Darsono.P (2013:144), biaya standar dibandingkan dengan biaya aktual melahirkan penyimpangan (varians).Analisis varians dapat dilakukan dengan menggunakan dua model yaitu varians harga atau varians tarif (price variansce or rate variansce) dan varians efisiensi (efficiency variansces). Teknik perhitungan kedua varians tersebut adalah sebagai berikut:

a. Varians Harga atau Varians Tarif

(Harga standar - Harga aktual) $\mathrm{x}$

Kapasitas actual

b. Varians Efisiensi

(Kapasitas standar - Kapasitas aktual)

x Harga standar

Jika biaya standar lebih besar daripada biaya aktual, maka melahirkan varians yang menguntungkan (favorable); dan sebaliknya jika biaya standar lebih kecil daripada biaya aktual, maka melahirkan varians yang tidak menguntungkan (unfavorable variansce).

Menurut Ari Purwanti dan Darsono.P (2013:149), varians penjualan adalah selisih antara penjualan standar dengan dan penjualan aktual yang dapat disajikan dalam bentuk varians volume penjualan dan varians harga.

Menurut Baldric S, Bambang S, Dody H, Eko W, dan Frasto B (2013:126), anggaran berikutnya yang perlu disusun adalah anggaran biaya penjualan. Anggaran tersebut menunjukan pengeluaran yang direnanakan untuk aktivitas penjualan dan distribusi. Seperti Overhead, biaya penjualan dapat dipecah ke dalam komponen tetap dan variabel. Unsur biaya penjualan, seperti komisi penjualan, biaya transportasi dan perlengkapan akan berubah jumlahnya mengikuti aktivitas penjualan. Gaji karyawan staf penjualan, depresiasi peralatan kantor penjualan, dan iklan merupakan biaya tetap. Rumus perhitungan biaya penjualan sebagai berikut :

Anggaran biaya penjualan $=$ Anggaran biaya penjualan tetap total + (Tarif biaya penjualanvariabel per unit $\mathrm{x}$ Unit yang dijual). 
Biaya penjualan standar dibandingkan dengan aktual biaya penjualan melahirkan penyimpangan (Varians) biaya penjualan.Jika biaya penjualan standar lebih besar daripada biaya penjualan aktual, maka melahirkan varians yang menguntungkan (fovorable variansce), dan sebaliknya jika biaya penjualan standar lebih kecil daripada biaya penjualan aktual, maka melahirkan varians yang tidak menguntungkan (unfavorabel variansce).

\section{METODOLOGI PENELITIAN}

Penelitian ini dilakukan di PT Combiphar Jakarta dengan objek penelitian Anggaran Penjualan sebagai variabel bebas pertama (X1), Anggaran biaya penjualan sebagai variabel bebas kedua (X2) dan Laporan Laba Rugi sebagai variabel terikat (Y). Pengukuran dari Anggaran Penjualan (X1) yaitu dengan menghitung selisihRealisasi Anggaran Penjualan - Anggaran Penjualan.Pengukuran dari Anggaran Biaya Penjualan yaitu dengan Anggaran Biaya Penjualan yang ada di PT Combiphar.Sedangkan Pengukuran dari Laba Rugi yaitu dengan perhitungan Laba yaitu Pendapatan - Biaya.Populasi dari penelitian ini adalah Laporan Keuangan dan Laporan Anggaran Operasional, sedangkan sampelnya adalah Laporan Laba Rugi, Laporan Anggaran Penjualan dan Laporan Anggaran. Teknik analisis data dalam penelitian ini adalah dengan menggunakan alat bantu SPSS, yaitu dengan uji regresi linier sederhana untuk pengujian parsial dan uji regresi berganda untuk pengujian simultan. Adapun pengujian hipotesis dengan uji $\mathrm{T}$ untuk uji parsial dan uji F untuk uji simultan.

\section{ANALISA DAN PEMBAHASAN}

Ringkasan Data Penelitian dapat dilihat pada tabel I sebagai berikut:

Tabel 1

Data Summary Laba Rugi, Varians Anggaran Penjualan \& Anggaran Biaya Penjualan Produk OBH 2012-2014

\begin{tabular}{|c|r|r|r|r|r|c|}
\hline Tahun & Laba Rugi & \% tase & $\begin{array}{c}\text { Varians } \\
\text { Anggaran } \\
\text { Penjualan }\end{array}$ & \% tase & \multicolumn{1}{c|}{$\begin{array}{c}\text { Anggaran Biaya } \\
\text { Penjualan }\end{array}$} & $\%$ tase \\
\hline 2012 & 20.673 .876 .920 & $6,17 \%$ & 2.653 .975 .919 & $-34,78 \%$ & 44.687 .761 .704 & $10,01 \%$ \\
\hline 2013 & 22.301 .141 .667 & $7,30 \%$ & 50.006 .249 & $-5207,29 \%$ & 51.870 .072 .903 & $13,85 \%$ \\
\hline 2014 & 24.592 .386 .519 & $9,32 \%$ & 13.251 .575 .864 & $99,62 \%$ & 59.112 .054 .844 & $12,25 \%$ \\
\hline
\end{tabular}




\section{Analisis Korelasi}

Berikut merupakan hasil dari analisis korelasi dari variabel-variabel penelitian:

Tabel 2

\section{Hasil Uji Korelasi}

\begin{tabular}{|ll|r|r|r|}
\multicolumn{1}{|c|}{ Correlations } \\
\hline
\end{tabular}

**. Correlation is significant at the 0.01 level (2-tailed).

Sumber: Data Diolah

Intepretasi dari tabel hasil korelasi diatas adalah hubungan Varians Anggaran Penjualan $\left(\mathrm{X}_{1}\right)$ Terhadap Laba Rugi $(\mathrm{Y})$ diperoleh hasil sebesar 0,594 dengan signifikan sebesar $0,000<0,05$. Angka ini menunjukkan Varians Anggaran Penjualan memiliki korelasi yang cukup kuat yaitu sebesar 59,4\%.terhadap Laba Rugi. Hubungan Anggaran Biaya Penjualan $\left(\mathrm{X}_{2}\right)$ Terhadap Laba Rugi (Y)diperoleh hasil sebesar 0,749 dengan signifikan 0,000 <
0,05. Angka ini menunjukkan Anggaran Biaya Penjualan memiliki korelasi yang kuat yaitu sebesar $74,9 \%$ terhadap Laba Rugi.

\section{Analisis Regresi}

1. Regresi Linier Sederhana

Hasil dari analisis regresi linier sederhana Variabel Anggaran Penjualan terhadap Laba Rugi ditunjukkan pada tabel dibawah ini:

Tabel 3

\section{Coeffisients Varians Anggaran Penjualan Terhadap Laba Rugi}

Coefficients $^{\mathrm{a}}$

\begin{tabular}{|ll|r|r|r|r|r|}
\hline \multirow{2}{*}{ Model } & \multicolumn{2}{|c|}{ Unstandardized Coefficients } & \multicolumn{2}{c|}{$\begin{array}{c}\text { Standardized } \\
\text { Coefficients }\end{array}$} & \multicolumn{1}{|c|}{} \\
\cline { 2 - 5 } & \multicolumn{1}{|c|}{$\mathrm{B}$} & \multicolumn{1}{|c|}{ Std. Error } & \multicolumn{1}{|c|}{ Beta } & \multicolumn{1}{c|}{ Sig. } \\
\hline 1 & (Constant) & 1809054099 & 63367869,55 & & 28,548 &, 000 \\
& $\begin{array}{l}\text { Varians Anggaran } \\
\text { Penjualan }\end{array}$ &, 153 &, 036 &, 594 & 4,306 &, 000 \\
\hline
\end{tabular}

a. Dependent Variable: Laba Rugi

Sumber : Data Diolah 
Dari tabel diatas dapat diketahui model persamaan regresi linier sederhana sebagai berikut :

$Y=a+\beta X$

$Y=1809054099+0,153 X$

Berdasarkan regresi linier sederhana diatas didapat konstanta sebesar 1809054099 artinya jika Varians Angggaran Penjualan $\left(\mathrm{X}_{1}\right)$ nilainya adalah 0 (tidak ada perubahan), maka Laba Rugi (Y) nilainya positif sebesar 1809054099 koefisien regresi positif sebesar $15,3 \%$. Jika Varians Anggaran Penjualan $\left(\mathrm{X}_{1}\right)$ meningkat sebesar 1 satuan, maka arus Laba Rugi (Y) akan meningkat sebesar $15,3 \%$. Artinya jika Varians Anggaran Penjualan sebesar 15,3\% maka Laba Rugi akan meningkat sebesar $15,3 \%$.

Hasil dari analisis regresi linier sederhana Variabel Biaya Penjualan terhadap Laba Rugi ditunjukkan pada tabel dibawah ini:

Tabel 4

\section{Coeffisients Anggaran Biaya Penjualan Terhadap Laba Rugi}

Coefficients $^{\mathrm{a}}$

\begin{tabular}{|c|c|c|c|c|c|c|}
\hline \multirow{2}{*}{\multicolumn{2}{|c|}{ Model }} & \multicolumn{2}{|c|}{ Unstandardized Coefficients } & \multirow{2}{*}{$\begin{array}{c}\begin{array}{c}\text { Standardized } \\
\text { Coefficients }\end{array} \\
\text { Beta } \\
\end{array}$} & \multirow[b]{2}{*}{$t$} & \multirow[b]{2}{*}{ Sig. } \\
\hline & & $B$ & Std. Error & & & \\
\hline & (Constant) & 535216646,1 & 209421750,9 & & 2,556 &, 015 \\
\hline & $\begin{array}{l}\text { Anggaran Biaya } \\
\text { Penjualan }\end{array}$ & ,310 &, 047 & ,749 & 6,601 &, 000 \\
\hline
\end{tabular}

a. Dependent Variable: Laba Rugi

Sumber : Output SPSS (2016)

Dari tabel diatas dapat diketahui model persamaan regresi linier sederhana sebagai berikut:

$\mathrm{Y}=\mathrm{a}+\beta \mathrm{X}$

$\mathrm{Y}=1836357921+0,387 \mathrm{X}_{2}$

Berdasarkan regresi linier sederhana diatas didapat konstanta sebesar 535216646,1 artinya jika Anggaran Biaya Penjualan $\left(\mathrm{X}_{2}\right)$ nilainya adalah 0 (tidak ada perubahan), maka Laba Rugi (Y) nilainya positif yaitu sebesar 0,310. Koefisien regresi variabel Anggaran Biaya Penjualan
$\left(\mathrm{X}_{2}\right)$ sebesar 0,310 artinya jika Anggaran Biaya Penjualan mengalami kenaikan 1, maka Laba Rugi (Y) akan mengalami peningkatan sebesar $31 \%$. Koefisien bernilai positif artinya terjadi hubungan positif antara Anggaran Biaya Penjualan dengan Laba Rugi, semakin naik Anggaran Biaya Penjualan maka akan semakin meningkatkan Laba Rugi.

2. Analisis Regresi Berganda

Hasil dari analisis regresi berganda adalah sebagai berikut:

Tabel 5

Hasil Analisis Regresi Linear Berganda

Model Summary ${ }^{\mathrm{b}}$

\begin{tabular}{|l|c|r|r|r|r|}
\hline Model & R & R Square & $\begin{array}{c}\text { Adjusted R } \\
\text { Square }\end{array}$ & $\begin{array}{c}\text { Std. Error of } \\
\text { the Estimate }\end{array}$ & $\begin{array}{c}\text { Durbin- } \\
\text { Watson }\end{array}$ \\
\hline 1 &, $759^{\mathrm{a}}$ &, 576 &, 550 & 302674611,4 & 2,011 \\
\hline
\end{tabular}

a. Predictors: (Constant), Anggaran Biaya Penjualan, Varians Anggaran

Penjualan

b. Dependent Variable: Laba Rugi

Sumber data: Output SPSS (2016)

Hal | 44 
Ouput diatas menjelaskan tentang nilai $\mathrm{R}^{2}$ (R Square) atau koefisien Determinasi, digunakan untuk mengetahui seberapa besar prosentase sumbangan pengaruh variabel independen secara bersama-sama terhadap variabel dependen. Apabila regresi menggunakan dua variabel independen maka yang digunakan adalah
$\mathrm{R}^{2}$ ( $\mathrm{R}$ Square), dari tabel output tersebut dapat diketahui nilia $\mathrm{R}^{2}$ ( $\mathrm{R}$ Square) adalah sebesar 0,576, artinya sumbangan pengaruh dari variabel independen yaitu sebesar $57,6 \%$, sedangkan sisanya sebesar $42,4 \%$, dipengaruhi oleh faktor lain yang tidak diteliti.

Uji Hipotesis

\section{Uji T}

a. Uji Parsial Variabel Anggaran Penjualan Terhadap Laba Rugi.

Tabel 6

Coefficients Varians Anggaran Penjualan Terhadap Laba Rugi (Uji t)

\begin{tabular}{|c|c|c|c|c|c|c|}
\hline \multicolumn{7}{|c|}{ Coefficients $^{a}$} \\
\hline & & \multicolumn{2}{|c|}{ Unstandardized Coefficients } & \multirow{2}{*}{$\begin{array}{c}\text { Standardized } \\
\text { Coefficients } \\
\text { Beta }\end{array}$} & \multirow[b]{2}{*}{$t$} & \multirow[b]{2}{*}{ Sig. } \\
\hline \multicolumn{2}{|c|}{ Model } & $\mathrm{B}$ & Std. Error & & & \\
\hline 1 & (Constant) & 1809054099 & 63367869,55 & & 28,548 &, 000 \\
\hline & $\begin{array}{l}\text { Varian Anggaran } \\
\text { Penjualan }\end{array}$ &, 153 &, 036 &, 594 & 4,306 &, 000 \\
\hline
\end{tabular}

a. Dependent Variable: Laba Rug

Sumber Data : Output SPSS (2016)

Berdasarkan tabel diatas, selanjutnya peneliti melakukan pengujian hipotesis secara parsial (Uji-t). Hipotesis penelitian yang akan di uji adalah sebagai berikut:

Ho1: Tidak terdapat pengaruh Varians Anggaran Penjualan terhadap Laba Rugi Ha1: Terdapat pengaruh Varians Anggaran Penjualan terhadap Laba Rugi

Pada tabel coefficient diperoleh $t_{\text {hitung }}$ variabel Varians Anggaran Penjualan terhadap Laba Rugi sebesar 4,306 dengan tingkat signifikansi 0,000 , kemudian dibandingkan dengan $t_{\text {tabel }}$ sebesar $2,03452, t_{\text {tabel }}$ dapat dicari pada tabel statistik $0,05 / 2=0,025$ (uji 2 sisi), dimana menentukan terlebih dulu df $=\mathrm{n}-\mathrm{k}-1 \rightarrow 36$ $2-1=33$, ( $\mathrm{k}=$ jumlah variabel independen, $\mathrm{n}=$ jumlah sampel), maka $\mathrm{t}_{\text {tabel }}$ sebesar 2,03452. $\mathrm{T}_{\text {hitung }}>\mathrm{t}_{\text {tabel }}(4,306>2,03452)$, maka Ho diterima dan Ha ditolak, artinya bahwa Terdapat Pengaruh Varians Anggaran Penjualan terhadap Laba Rugi.

b. Uji Parsial Variabel Biaya Penjualan Terhadap Laba Rugi

Tabel 7

Coefficients Anggaran Biaya Penjualan Terhadap Laba Rugi (Uji t)

Coefficients $^{a}$

\begin{tabular}{|c|c|c|c|c|c|c|}
\hline & & \multicolumn{2}{|c|}{ Unstandardized Coefficients } & \multirow{2}{*}{$\begin{array}{c}\begin{array}{c}\text { Standardized } \\
\text { Coefficients }\end{array} \\
\text { Beta }\end{array}$} & \multirow[b]{2}{*}{$t$} & \multirow[b]{2}{*}{ Sig. } \\
\hline \multicolumn{2}{|c|}{ Model } & $B$ & Std. Error & & & \\
\hline 1 & (Constant) & 535216646,1 & 209421750,9 & & 2,556 &, 015 \\
\hline & $\begin{array}{l}\text { Anggaran Biaya } \\
\text { Penjualan }\end{array}$ &, 310 &, 047 &, 749 & 6,601 &, 000 \\
\hline
\end{tabular}

Sumber data : Output SPSS (2016) 
Hipotesis penelitian yang akan di uji dirumuskan menjadi hipotesis statistik berikut:

$\mathrm{Ho}_{2}$ : Tidak terdapat pengaruh Anggaran Biaya Penjualan terhadap Laba Rugi

Ha2: Terdapat pengaruh Anggaran Biaya Penjualan terhadap Laba Rugi

Pada tabel diatas coefficiens diperoleh $t_{\text {hitung variabel Anggaran Biaya Penjualan }}$ sebesar 6,601 dengan tingkat signifikasi 0,000, kemudian dibandingkan dengan $\mathrm{t}_{\text {tabel }}$ sebesar 2,03452, ternyata nilai $\mathrm{t}_{\text {hitung }}$ $(6,601)>t_{\text {tabel }}(2,03452)$, maka Ho ditolak dan Ha diterima, artinya bahwa Terdapat Pengaruh Anggaran Biaya Penjualan terhadap Laba Rugi.

\section{Uji F}

Uji Simultan Variabel Anggaran Penjualan dan Biaya Penjualan terhadap Laba Rugi

Tabel 8

Coefficients Varians Anggaran Penjualan dan Anggaran Biaya Penjualan Terhadap Laba Rugi (Uji f)

ANOVA $^{a}$

\begin{tabular}{|c|c|c|c|c|c|c|}
\hline & & $\begin{array}{l}\text { Sum of } \\
\text { Squares }\end{array}$ & df & Mean Square & $\mathrm{F}$ & Sig. \\
\hline \multirow[t]{3}{*}{1} & Regression & $4,103 E+18$ & 2 & $2,052 \mathrm{E}+18$ & 22,395 &, $000^{6}$ \\
\hline & Residual & $3,023 E+18$ & 33 & $9,161 \mathrm{E}+16$ & & \\
\hline & Total & $7,126 \mathrm{E}+18$ & 35 & & & \\
\hline
\end{tabular}

a. Dependent Variable: Laba Rugi

b. Predictors: (Constant), Anggaran Biaya Penjualan, Varians Anggaran Penjualan

Sumber data : Output SPSS (2016)

Berdasarkan output hasil pengujian SPSS dapat disimpulkan bahwa hasil $F_{\text {hitungsebesar 22,395 dengan tingat }}$ signifikan ,000, dan $\mathrm{F}_{\text {tabel }}$ sebesar 3,28.

\section{KESIMPULAN DAN SARAN}

\section{Kesimpulan}

Berdasarkan hasil penelitian dan pembahasan pada bab sebelumnya, maka diperoleh simpulan sebagai berikut:

1. Berdasarkan hasil Uji-t Varians Anggaran Penjualan terhadap Laba Rugi memiliki nilai dimana $t_{\text {hitung }}(4,306)>t_{\text {tabel }}(2,03452)$ dengan tingkat signifikan sebesar 0,000 lebih kecil dari 0,05. Dari hasil pengujian terlihat, maka keputusannya adalah Ho ditolak dan Ha diterima, artinya bahwa
$F_{\text {hitung }}>F_{\text {tabel }}(22,395>3,28)$. Dengan demikian Ho ditolak dan Ha diterima, artinya secara simultan Varians Anggaran Penjualan danAnggaran Biaya Penjualan Berpengaruh Terhadap Laba Rugi.

Varians Anggaran Penjualan berpengaruh signifikan terhadap Laba Rugi dengan signifikan sebesar 0,000.

2. Sedangkan hasil Uji-t Anggaran Biaya Penjualan Terhadap Laba Rugi memiliki nilai dimana $t_{\text {hitung }}(6,601)>$ $t_{\text {tabel }} \quad(2,03452)$ dengan signifikan sebesar 0,000 lebih kecil dari tingkat kesalahan (alpha) yaitu 0,05. Dari hasil pengujian terlihat, maka keputusannya adalah Ho ditolak dan $\mathrm{Ha}$ diterima, 
artinya bahwa Anggaran Biaya Penjualan berpengaruh signifikan terhadap Laba Rugi dengan signifikansi sebesar 0,000 .

3. Berdasarkan hasil Uji-f Varians Anggaran Penjualan dan Anggaran Biaya Penjualan terhadap Laba Rugi bahwa $f_{\text {hitung }}(22,395)>\mathrm{f}_{\text {tabel }}(3,28)$ dengan signifikan $0,000<0,05$. Dari hasil pengujian terlihat, maka keputusannya adalah Ho ditolak dan Ha diterima. Artinya terdapat pengaruh Varians Anggaran Penjualan dan Anggaran Biaya Penjualan secara simultan terhadap Laba Rugi.

\section{Saran}

Adanya varians atas anggaran dengan realisasinya memang tidak dapat dihindari, yang dapat diupayakan adalah meminimalisasi varians tersebut. Varians itu sendiri ada yang bersifat menguntungkan (Favorable) dan varians yang tidak menguntungkan (Unfavorable). Supaya varians tidak menguntungkan yang terjadi terhadap biaya trade promo dapat diminimalisasi yaitu dengan cara meningkatkan komunikasi antar divisi, terutama bagian yang bertanggung jawab atas biaya tersebut lebih memperhatikan lagi saldo ketersediaan anggaran biaya yang masih tersisa sebelum melakukan kerjasama dengan outlet untuk melakukan kerjasama promosi.

\section{DAFTAR PUSTAKA}

Ari Purwanti, Darsono Prawironegoro, 2013, Akuntansi Manajemen, Edisi ke-3 Revisi, Jakarta: Mitra Wacana Media

Baldric Siregar, Bambang Suripto, Dody Hapsoro, Eko Widodo Lo, \& Frasto Biyanto, 2013, Akuntansi Manajemen, Jakarta: Salemba Empat

Dermawan Sjahrial, Djahotman Purba, 2012 AKUNTANSI

MANAJEMEN, Jakarta : Mitra Wacana Media

Didit Herlianto, 2015, Anggaran Keuangan, Yogyakarta, Gosyen Publishing

Don R. Hansen, Maryanne M.Mowen, 2012, Akuntansi Manajerial, Edisi ke-8, Buku 1, Jakarta: Salemba Empat

Duwi Priyatno, 2013, Analisis KORELASI, REGRESI dan MULIVARIATE dengan SPSS, Cetakan I, Yogyakarta : Gava Media.

Frankyy Husin 2010, Analisis Pengendalian Biaya dan Varians Anggaran dengan Realisasi Penjualan Pada PT. Vinayaka Abadi, Jurnal, POLTEK PalComTech Palembang.

Garrison Noreen Brewer, 2013, Akuntansi Manajerial, Edisi ke-14, Buku 1, Jakarta: Salemba Empat 
Ghazali, Imam, 2011,Aplikasi Analisis Multivariate Dengan Program IBM. Semarang: UNDIP

Hery, 2011, Teori Akuntansi, Cetakan ke-2, Jakarta: Prenada Media Group

Jefry Katili. 2013, Analisa Varian Biaya Operasional Dalam Pengukuran Efektivitas Pengendalian Biaya Operasional PT. Asuransi Jiwasraya (Persero). Jurnal, Universitas Sam Ratulangi Manado.

L.M. Syamryn, 2013, Akuntansi Manajemen, Edisi Revisi, Jakarta: Kencana Prenadamedia Group

Rudianto, 2013, Akuntansi Manajemen, Jakarta: Erlangga

Sofyan Siregar, 2013, Metode Penelitian Kuantitatif, Jakarta: Kencana Prenada Media Group
S.R. Soemarso, 2013, Akuntansi Suatu Pengantar, Jakarta: Salemba Empat.

Sugiyono, 2012, Metode Penelitian Kuantitatif Kualitatif dan R\&D, Cetakan ke-17, Bandung: Alfabeta

Singgih Santoso, 2014, Statistik Parametrik Konsep dan Aplikasi dengan SPSS, Jakarta, PT Gramedia

V.Wiratna Sujarweni, 2015, SPSS untuk PENELITIAN, Yogyakarta : Pustaka Baru Press

Watania, 2013, Analisis Varians Biaya Operasional Dalam Mengukur Efektivitas Pengendalian Biaya Operasional Pada Kantor Wilayah VI PT Pegadaian (Persero) Manado, Skripsi, Universitas Sam Ratulangi Manado. 